\title{
Post-Traumatic Growth and Identity Construction in Covid-19 Messages Delivered to the People of Ghana by President Nana Akuffo Addo
}

\author{
Cynthia Logogye ${ }^{1, *}$, Bernard Asafo-Duho ${ }^{1} \&$ Joseph B.A. Afful $^{1}$ \\ ${ }^{1}$ Department of English Education, University of Education, Winneba, Ghana \\ *Correspondence: Department of English Education, University of Education, Winneba, Ghana. E-mail: \\ clogogye@yahoo.com
}

Received: September 21, 2021

Accepted: November 22, $2021 \quad$ Online Published: December 14, 2021

doi:10.5430/ijelt.v9n1p1

URL: https://doi.org/10.5430/ijelt.v9n1p1

\begin{abstract}
This work analyses post-traumatic growth in Covid-19 addresses delivered to the people of Ghana by President Nana Akuffo Addo. We draw on Post-Traumatic Growth Theory to explain how Akuffo Addo constructs a new identity for himself and the nation in order to navigate through the pandemic and forge an agenda of growth and prosperity for Ghana. The study employs a linguistic content analysis approach. The data consists of twenty different speeches from the president to the people. The speeches are first analysed and coded manually for the five main tenets of Post-Traumatic Growth (PTG) identified in the updates. Consequently, the linguistic markers that are used in reconstructing the Ghanaian identity in response to the pandemic are delineated and mapped to the goals of the president using the Linguistic Inquiry and Word Count 2015 (LIWC2015; Pennebaker et al., 2015) software; a vocabulary analysis tool. The analysis showed that there was a high prevalence of personal pronoun use, use of positive-emotion words, and cognitive-processing words. This confirms our hypothesis that linguistic markers can be used to detect PTG.
\end{abstract}

Keywords: Covid-19 addresses, Ghana, post-traumatic growth, identity construction

\section{Introduction}

The deadly COVID-19 wreaked havoc globally. It had impacts on the economies of nations and greatly affected social transactions and the relationship between and among nations. Governments had to institute measures to maintain social cohesion, national stability while fighting the global pandemic. With the introduction of vaccines, vaccine politics is rife. There is a sharp difference between the developed and developing nations because some nations reject vaccines due to fake news, whereas others are overstocking supplies.

Leaders the world over are (re)defining national identities while adopting strategies to contain the social changes that the virus has brought about. A UNDP (2021) analysis of long-term socio-economic impacts of COVID-19 across diverse African contexts reveals that the pandemic has claimed over 100,000 African lives and nearly 4 million cases have been recorded so far leaving diverse effects on the continent and varied socioeconomic implications.

There is no single Africa COVID-19 story. Africa leaders address covid 19 depending on peculiar problems prevalent in their own countries and they try to design appropriate strategies in dealing with the pandemic. Basically, issues such as gender bias, trade, and regional integrations are the requirements advocated for by leaders. President Nana Akuffo Addo of $\mid$ Ghana has relentlessly led the nation in a fight against the global pandemic. To keep Ghanaians in the loop as the fight rages on, he delivers periodic updates to the nation. These updates are captioned "measures taken to contain the virus".

Undoubtedly, the pandemic is a traumatic event that caused panic and anxiety in Ghana. The government of Akuffo Addo had to impose lockdowns and restrictions that were meant to contain the virus. These restrictions did affect the livelihoods of many and left a lot of people experiencing, for the first time, life changes. Sickness and death devastated many. News channels churned out reports of the devastation and mourning, and worship became severely restrictive thus curtailing even the grief process. Recently, a meta-analysis of 17 studies published on the pandemic (Salari et al 2020) has associated the pandemic with high levels of stress, anxiety, and depression among the populace. Countries 
with higher levels of economically vulnerable people are expecting surges in mental health issues as a result of austerity measures the pandemic brought (Cadagnone et al., 2020).

While global news channels praise some leaders for dealing with the pandemic well, others are vilified for using measures not backed by science. Some female leaders were much-touted as being better leaders in the crisis. In fact, substantial data exists to show that female leaders around the globe responded better and managed the COVID-19 pandemic better than their male counterparts. Leaders singled out for praise include leaders of Germany, Finland, Taiwan, Denmark, and New Zealand. In a 2020 article in the Harvard Business Review Zenger \& Folkman opine that during the Covid-19 crisis, anecdotally women leaders were perceived to be doing a better job. Zenger \& Folkman (2020) found that outcomes related to Covid-19, including the number of cases and deaths, were systematically better in countries led by women. Another study by Bruce, Cavgias, Meloni, and Remígio (2021) looked at governors in the U.S. and similarly found that states with female leaders had lower fatality rates.

Interestingly, Ghana's Akuffo Addo was also singled out for praise by the WHO for handling the pandemic well as compared to other African leaders. For some months in 2020, there were no cases of COVID reported in Ghana while neighbouring countries had double-digit cases. Taylor and Berger (2020) report that when it comes to the coronavirus response, "the World Health Organization is studying some of Ghana's techniques". Akuffo Addo's government took pride in the measures put in place to fight the pandemic and resorted to giving regular updates to the nation to reassure the citizens. But when the cases surged and the country started recording deaths, harsh measures had to be taken, unpleasant decisions had to be made and opposition to these measures was rife.

In a country that is highly polarised politically with very close election results announced every four-year cycle, it could amount to political suicide if the citizens are not brought on board to fight the pandemic. The leader had to align with the hopes and aspirations of the people while constructing an identity of a commander in chief who could be trusted by Ghanaians. The present study thus investigates how the updates are used as a political tool aimed at creating national cohesion amidst a traumatic experience.

Basically, the study investigates how President Akuffo Addo constructs a new identity for himself and Ghanaians in order to lead them through the pandemic and forge an agenda of growth and prosperity for the nation.

\section{Theoretical Framework}

We draw on Post-Traumatic Growth Theory to explain how Akuffo Addo constructs a new identity for himself and the nation in order to navigate through the pandemic and forge an agenda of growth and prosperity of Ghana for the period after the pandemic. Post-Traumatic Growth (PTG) has been defined as the subjective experience of positive psychological changes in the aftermath of a traumatic experience (Tedeschi, Park \& Calhoun, 1998).

According to the theory, traumatic growth is not a monolithic construct. It encompasses five distinct dimensions of growth:1) changes in how people relate to others; 2) recognition of new possibilities;3) a sense of greater personal strength; 4) changes toward spirituality, and 5) greater appreciation of life. Post-traumatic growth in response to stressors has been investigated substantially by scholars within the context of motor accident survivors (Nishi et al 2010) natural disasters such as earthquakes (Nakagawa et al, 2016, First et al 2018) hurricanes (Lowe et al 2013 Matthew et al 2019).

The theory has also been applied in making meaning out of individual life experiences in many studies. These studies include Elena, Aresi, Martha \& Pozzi (2021); Teixeira (2013) and Vazquez et al, and Stallard, Pereira \& Barros 2021. PTG is experienced by caregivers of cancer patients. It was reported in people dealing with the effects of COVID. For instance, Stallard et al (2021) report that $88.6 \%$ of 385 respondents to a survey identified positive outcomes from COVID-19, most commonly related to the PTG domains of improved relationships, a greater appreciation of life, discovering and embracing new possibilities, and positive spiritual change.

Just as individuals or homogenous groups have identities that are constructed and shaped by traumatic experiences, nations also have identities that respond to change. National identities undergo dramatic change during periods of traumatising debilitating events since "nations and national identity are social constructions that exist as political, cultural inventions and local tactics" (Clifford,1988:12). National identity can be perceived as an emergent, interpretive process rather than a static structure. Post-Traumatic growth can be linked to a number of linguistic markers.

Since the emergence of the theory, it is taken for granted that linguistic markers that were predictive of post-traumatic stress and have been widely used in determining those at risk and in need of urgent care could be investigated to 
explain other post-traumatic adjustments. Kleim, Horn, Kraehenmann, Mehl \& Ehlers (2018) argue that the use of more first-person singular pronouns, use of less cognitive processing words, use of more death-related words were linguistic markers of post-traumatic stress disorder and thus highly predictive of PTSD in the absence of psychological tests.

Similarly, Hoyt \& Pasupathi (2008) used two linguistic variables, the difference between positive and negative word counts and the difference between singular and plural personal pronouns as predictors in determining apparent recovery from traumatic experiences. Several studies (Morris, Shakespeare-Finch Rieck \&Newberry, 2005; Taku, Cann, Cahoun, \& Tedeshi, 2008; Zoellner \& Maercker, 2006) found a positive relationship between PTG and PSTD.

As linguists, we are not interested in the correlations of these psychological variables. Our responsibility has always been to show how linguistic variables can be seen as related to these psychological variables thus giving those providing treatment and psychological counselling to people quick, cost-effective ways to better manage clients. In third-world countries, access to standardized tests and measures to determine PSTD or PTG is limited. Thus, in this study, we seek to show that personal pronoun use and the use of positive words are predictors of post-traumatic growth and adjustments in personal and national identity construction.

In this study, we use the Linguistic Inquiry and Word Count 2015 (LIWC2015) software (the latest version) in fishing out the variables of Post-Traumatic Growth. The LIWC output software is used in analysing both linguistic and psychological texts. The software is used in calculating word count; the raw number of words within a file, and words per sentence; the mean number of words within each sentence within the file. LIWC2015 also includes four summary variables; analytical thinking, clout, authenticity, and emotional tone. These variables are made from previous language research. Clout refers to the relative social status, confidence, or leadership people display through their writing or talking (Kacewicz, Pennebaker, Davis, Jeon, \& Graesser, 2014). They, however, draw a distinction between clout and the LIWC2015 power variable. Power or need for power reflects people's attention to or awareness of relative status in a social setting. You can have a confident leader who has no interest in other people's standing in the social hierarchy.

The LIWC also includes both positive emotion and negative emotion dimensions, however, the tone variables put the two dimensions into a single summary variable Cohn, Mehl, \& Pennebaker, 2004. The algorithm is built so that the higher the number, the more positive the tone. The LIWC is a widely used lexicon-based tool. The history of Linguistic Inquiry and Word Count (LIWC) began in the early 1990s. Since then, two revised versions have been launched: LIWC2001(Penebaker et al., 2001) and LIWC2007 (Penebaker et al., 2007). The latest release, LIWC2015 (Penebaker et al., 2015) was introduced more as a new instrument than an updated variant of the old versions. The new version tends to detect very similar linguistic patterns. The various versions of the LIWC have been deemed the most preferred for automatic content analysis in social science research (Dudau and Sava, 2021).

\section{Methods and Procedure}

The current study is a linguistic content analysis of the updates to the nation. The speeches are first analysed and coded manually for the five main tenets of PTG identified in the updates. Consequently, the linguistic markers that were used in reconstructing the Ghanaian identity in response to the pandemic are delineated and mapped to the goals of the president using the Linguistic Inquiry and Word Count 2015 (LIWC2015; Pennebaker et al., 2015) software, a closed-vocabulary approach tool well-suited for linguistic and psychological text analysis of traumatic experiences. We hypothesise that pronoun use, the proportion of negative emotion words against positive emotion words are related to post-traumatic growth and the creation of a new Ghanaian identity. The LIWC output is compared with findings from previous studies related to post-traumatic stress to draw a contrast.

The data consists of twenty (20) different speeches of President Akuffo Addo obtained from info@moh.gov.gh. He typically delivers the speeches on selected Sunday evenings and it is broadcast live on Media outlets. Copies of the speeches are then made available to the public in written form. In all 37282 words were involved. Out of the 20 updates, a total of ninety-three (93) paragraphs devoted to issues of post-traumatic growth were extracted from the data and used in the analysis.

\section{Results and Discussion}

Table 1 below presents the frequency of occurrence of the various dimensions of post-traumatic growth that represent changes in the identity of Ghanaians in the face of the coronavirus pandemic followed by a detailed analysis of the 
data.

Table 1. Dimensions of Post-Traumatic Growth

\begin{tabular}{llllll}
\hline $\begin{array}{l}\text { Changes in how } \\
\text { people relate } \\
\text { with others }\end{array}$ & $\begin{array}{l}\text { Recognition of } \\
\text { new possibilities }\end{array}$ & $\begin{array}{l}\text { A sense of greater } \\
\text { personal strength } \\
\text { (resilience) }\end{array}$ & $\begin{array}{l}\text { Changes } \\
\text { towards } \\
\text { spirituality }\end{array}$ & $\begin{array}{l}\text { Greater } \\
\text { appreciation } \\
\text { of life }\end{array}$ \\
\hline TOTAL & 13 & 46 & 12 & 8 \\
\hline
\end{tabular}

The table above represents the frequency of occurrence of the various dimensions of post-traumatic growth of Ghanaians demonstrated in the updates of Covid-19 delivered to the people by President Nana Akuffo Addo. The dimensions represent the identity of the Ghanaian people in the face of the Covid-19 pandemic. Through those dimensions, President Akuffo Addo portrays the Ghanaian as resilient, evolving, and optimistic. Of all the identities constructed, the data reveals that the president identifies Ghanaians mostly, as a people with resilience; a people with a sense of greater personal strength even in the face of adversity.

Groups have identities that are constructed and shaped by traumatic experiences, nations also have identities that respond to change. National identities undergo dramatic change during periods of traumatising debilitating events since "nations and national identity are social constructions that exist as political, cultural inventions and local tactics" (Clifford,1988:12). The data analysed in this work has revealed how the experiences of Covid-19 have shaped the identity of President Nana Addo, his government, and the people of Ghana.

\subsection{A Sense of Greater Personal Strength}

In the addresses to the nation, firstly, the president constructs an identity of the resilience of his own personality through the use of first-person pronouns, his government, and then the Ghanaian people in that traumatic experience, the novel Coronavirus outbreak, a medical crisis that is bringing in its wake deaths and economic difficulties, and is spreading fear and panic throughout the world. As a politician whose aim is to convince the people of his capability to handle that situation, he makes use of first-person pronouns such as I, myself, my, and words discrepancy, demands, dedicate, determined, to show that he is capable of dealing with the virus. The following exemplifies the point:

\section{Extract 1}

Fellow Ghanaians, the Oath of Office I swore on $7^{\text {th }}$ January 2017 demands that I dedicate myself to the service and well-being of you, the Ghanaian people. It is my job to protect you, and I am determined to do just that. (28-3-2020).

The president, through the use of the pronouns I, myself, my and the words of discrepancy, demands, dedicate, determined, portrays himself as one with an overarching aim of providing relief to the ordinary Ghanaian and being able to find more resources to strengthen the productive sectors of the economy to ensure sustained economic activity. In extract 1 above, he constructs an identity of trustworthiness and dedication to serving his nation. As part of his construction of an identity of dedication to serve his country, he considers it a privilege to be the president of the country in these trying moments. He considers himself capable of leading his country out of the crises, and he demonstrates how resilient he is in the fight against the pandemic as illustrated in the words in extract 2 below;

\section{Extract 2}

I have, first of all, to tell you how proud and privileged I am to be your President, not just to fight for you, but also to fight with you, and to help shepherd our country out of this crisis. (9-4-2020)

Apart from the construction of an identity of the resilience of his personality, the president in the addresses through the use of third-person subject, government, also constructs an identity of resilience concerning his government. It has been assumed that one important variable in post-disaster functioning is resilience (Marshall, Abate \&Venta, 2020). He shows a sense of greater strength of his government towards combating the spread of the virus and bringing relief to Ghanaians in all areas of their lives. The president expresses the ability of his government through the demonstrative subject 'this government' to encourage Ghanaians of the ability of the present government to help them out of the crises as it is natural that most individuals will experience debilitating stress disorders symptoms. An identity of assurance is therefore created to calm down nerves. The illustration in extract 3 below exemplifies the point: 


\section{Extract 3}

This Government is resolved and determined, in this second phase, to help Ghanaians fully return to their daily routines, whether it be going to work, going to school, going to a funeral, or going to worship - all the while taking full precautionary measures to protect ourselves and our families from the virus. (26-7-2020)

Thirdly, the president constructs an identity of the resilience of the Ghanaian people, expressing their ability to defeat the ravage of the virus. The use of the linguistic item, 'we', 'our' first-person plural pronouns reveal a co-operate identity in the fight against the virus. Also, the use of the construction, 'we are capable' adds valuable information of an identity of co-operating resilience in fighting the virus. Through the following linguistic choices, we see resilience and growth in the context of adversity.

\section{Extract 4}

We have demonstrated not only to ourselves but also to the entire world, that we are capable of charting our own path towards containing the spread of this disease. We must all be proud that we have become a reference point for others on how to combat it. (31-5-2020)

As a result of co-operating resilience of the Ghanaian people, observing the principles of social distancing, the wearing of masks, and the enhanced hygiene protocols, which are considered the most effective defences against the virus, people have been saved from dying of the virus in their hundreds as was initially anticipated. The opposite is seen daily in some other countries. The successes chalked have been as a result of the common efforts of the Ghanaian people. Ghanaians by their nature like to co-operate in lots of things, especially in their social life. As a result, the president constantly constructs an identity of cooperativeness of Ghanaians in the fight against the virus. In essence, the successes chalked in the fight against the virus is partly due to an identity of collective effort and group co-operation of Ghanaians as revealed in the expressions, "strong co-operation of you", 'Our common efforts', as demonstrated in extracts 5 and 6 below:

\section{Extract 5}

As I have already said, everything that has been achieved, so far, would not have been possible without the strong co-operation of you, the Ghanaian people. (31-5-2020)

\section{Extract 6}

Our common efforts have been modestly successful in containing the virus and minimizing its spread. (9-4-2020)

Notwithstanding the resilience of the president in his fight against the pandemic, he is also aware of the existence of political opponents and other threats to his identity. Thus, he craftily appeals to the common elements that define the Ghanaian as he presents copious reasons for all his actions or inactions in a bid to rally the whole nation together in fighting the pandemic which he construes as a common enemy. The following illustrates the point:

\section{Extract 7}

The cynics question our capacity for the maintenance of discipline in this period, and in its aftermath; however, I am confident that we will prove them wrong. Ghanaians always rise to the occasion, and we will do so again. United, we are going to win this battle. (5-4-2020)

The findings above suggest that linguistic analysis can contribute to the prediction of resilience after a disaster.

\subsection{Changes in How People Relate with Others}

The outbreak of the pandemic has brought some changes in the way people relate with others. In the face of the pandemic, people no longer related as before. Some language patterns serve to reveal the changes in the way people are now to relate with others. These changes affirm the assertion that individuals or homogenous groups have identities that are constructed and shaped by traumatic experiences just as nations also have identities that respond to change. Given this, Akuffo Addo uses narratives to forge congruence between the known Ghanaian identity and the threats that the pandemic poses, which he redefined to accommodate change while constructing a new identity that is based on behavioural change. The changes in relationship are typically revealed with the language patterns, "We are used to attending Easter Conventions", "However, I am urging all of us to do the exact opposite of what we have been used to.", "stay at home." With these language patterns, individual identities are constructed and given prominence over group identities. This is illustrated below in extract 8 , 


\section{Extract 8}

We are used to attending Easter Conventions, making-merry, visiting friends and family, and having a good time. Yes, like a lot of you, I was also looking forward to visiting Kwahu during this time of the year, which I have been doing for several years. However, I am urging all of us to do the exact opposite of what we have been used to for many years. Stay at home. (9-4-2020)

Ghanaians are noted to be a united people, they stand together in joy and pain. This is depicted in their marriages and funerals where there are usually large social gatherings to grace the occasion. One's occasion is deemed as successful with the number of people on attendance. However, with the emergence of Covid-19, there has to be a change of identity where people could no longer gather in huge numbers to grace occasions of their family and friends. Hence, some old identities had to be sacrificed to pave way for new ones. The following exemplifies the point:

\section{Extract 9}

I ask you to keep your distance from your parents, grandparents, and extended family, and celebrate this holiday apart. Do not host a big family gathering, and sternly refuse to attend one if you are invited. Your relatives will understand you are doing this out of love for them. Please, make that sacrifice. (9-4-2020)

However, the president through the use of emotional words cautions against the stigmatisation of people who contracted and have recovered from the virus. People no longer have that sense of community, which is a positive Ghanaian attribute, especially, with people who have recovered from the virus. He reminded the people of the proverbial saying that "being a Ghanaian means we look out for each other". The following example is provided for illustration,

\section{Extract 10}

There is nothing shameful about testing positive. We do not have to lose our sense of community because of this pandemic. (14-6-2020)

Extract 10 above is meant to appeal to the emotions of people to stop stigmatisation against Covid-19 victims.

\subsection{Recognition of New Possibilities}

In response to the threats that the pandemic poses, the president, Nana Addo, seeks to redefine the identity of Ghanaians to accommodate change while constructing a new identity based on the proverbial optimistic resilience and entrepreneurial spirit of the Ghanaian. He paints a picture of the Ghanaian as evolving; one that can recognise opportunities/possibilities, even in times of crisis.

In the face of the pandemic, all nations in the world ultimately stand alone. There is therefore the need for people to look within and mobilise their own resources and deal with the virus as reflected in the saying, everybody for himself, God for us all. The virus has forced some identities out of the Ghanaians who have been transformed to produce and consume local goods. Marshall Abate \& Venta (2020) attests that in a disaster environment where resources are scarce, advances in technology have been a tremendous asset in utilizing novel methodologies. In the face of the pandemic, Ghanaians have proved their capability of self-reliance as the movement of people and goods worldwide had been restricted except for essential goods and services. Ghanaians were seen to have the capacity for technological advancement. Necessity, they say, is the mother of invention. The crisis necessitated a number of inventions to meet local demands; the Ghanaian sense of enterprise and innovation began to be felt; Veronica buckets were given some technological facelift to serve the purpose of handwashing as well as solar-powered handwashing sink, COVID-19 prevention electronic bucket all invented by private individuals. These are placed at the entrances of offices, schools, and enterprises, etc. for hand washing. The following extract illustrates how innovative Ghanaians can be in times of crisis:

\section{Extract 11}

I am equally impressed with the invention of a solar-powered handwashing sink by Jude Osei from Kumasi, and the "COVID-19 prevention electronic bucket" made by Kelvin Owusu Dapaah and Richard Boateng, both students of Obuasi Senior High and Technical School. (28-3-2020)

The Ghanaian sense of enterprise and innovation was also felt in the fashion and pharmaceutical industries. They had to step up in the production of PPEs; nose masks, hand sanitisers, etc. to serve the local population in the face of a global shortage. This gave the Ghanaian a new identity of local manufacturer and consumer of locally manufactured goods who was hitherto, overly dependent on foreign manufactured goods including food and medical supplies and products. All these are indicators of Post-Traumatic Growth (PTG). Extract 12 illustrates the point: 


\section{Extract 12}

We have lessened our dependence on foreign imports and scaled up significantly domestic production and distribution of personal protective equipment to our healthcare workers, evidenced ..........in the provision of face masks, head covers, surgical scrubs, and gowns. (31-5-2020)

\subsection{Changes Towards Spirituality}

Ghanaians are noted to be very spiritual. They believe in the supernatural power of God to help them in the face of adversaries. In that regard, at the outbreak of the pandemic, the president, Nana Addo in his third update to the nation, on March 15, 2020, declared at least, a one-day fast to be observed by all Ghanaians. The president as well as the majority of Ghanaians believed that it would only take the special grace of God for the nation to be spared of the ravage of the virus, seeing the death tolls, even, in countries of the world that are far advanced in the area of medicine and provision of health care facilities. The president, therefore, portrays the Ghanaian as one with hope and optimism to survive the crises with the help of God. The examples in extracts 13 and 14 are given for illustration:

\section{Extract 13}

The Ghanaian people, mercifully, are not dying of the virus in the hundreds and thousands that were earlier anticipated and predicted, and that is being seen daily in some other countries. The behaviour of this virus has baffled the experts and defied most predictions. ..... And, I dare say, it is the Grace of God (26-7-2020)

\section{Extract 14}

We have prayed to Almighty God to heal our land, and I know that, by the Grace of God, He has heard our cry. We should pray, of course, that the Almighty continues to shield us (28-3-2020)

Throughout the speeches, Nana Addo constantly expresses the optimism of the Ghanaian to emerge out of the pandemic strongly with faith in God. He constantly ended the speeches by portraying the nation as one dependent on God for her greatness and strength. See extracts 15 and 16 below:

\section{Extract 15}

Fellow Ghanaians, ultimately, the Battle is the Lord's, and, with faith in Him, we will emerge from this greater than before (31-5-2020)

\section{Extract 16}

God bless our homeland Ghana and make her great and strong. (5-4-2020)

\subsection{Greater Appreciation of Life}

The virus also brought with it a greater appreciation of life. Before the pandemic, certain offers of life were taken for granted and least appreciated;

\section{Extract 17}

...the health of loved ones; the freedom to work and to congregate; the luxury of spontaneity; and the simple comfort of a handshake or a hug. (9-4-2020)

All the above were very common among Ghanaians and most people of the world but given the least appreciation, however, the outbreak of the pandemic has brought a deeper sense of appreciation of all those blessings that were taken for granted. In the speech of the president, the fight against Coronavirus has served as a humbling reminder of the things that matter, the things that cannot be bought, and the things that, all too often, go unappreciated.

\subsection{Changing the Identity Narrative}

Having examined how the five tenets of post-traumatic growth are woven into the updates given by the president, we now turn attention to the efforts the president made to rally the nation together to fight a common enemy.

We argue that the president uses the updates to achieve a number of rhetorical goals that help to portray the Ghanaian as a resilient, evolving, and optimistic entity that rises above any threat. In doing this, he is consciously hyping his own identity as a caring, forthright leader who empathises with the ordinary Ghanaian. Extracts 18, 19, and 20 below illustrate how President Nana Addo constructs an identity of a caring leader for himself and an identity of resilience indicating how capable he and the Ghanaian people are in fighting the virus through the use of personal pronouns $I$, and we showing individual and collective efforts: 


\section{Extract 18}

I have, first of all, to tell you how proud and privileged I am to be your President, not just to fight for you, but also to fight with you, and to help shepherd our country out of this crisis. (9-4-2020)

\section{Extract 19}

We have demonstrated not only to ourselves but also to the entire world, that we are capable of charting our own path towards containing the spread of this disease. (31-5-2020)

\section{Extract 20}

We must all be proud that we have become a reference point for others on how to combat it. (31-5-2020)

The president empathises with the painful sacrifices everyone must make to defeat the virus. On the other hand, he is aware of the existence of political opponents and other threats to his image thus he craftily appeals to the common elements that define the Ghanaian as he presents copious reasons for all his actions or inactions in a bid to rally the whole nation together in fighting the pandemic, which he construes as a common enemy. This led him to make a shift in the identity construction narrative.

\subsection{Identity Construction Marked by Subtle Ideological Wars}

From Table 2, the high proportion of positive emotion words contrasts with the negative emotion words just as power words have a remarkable percentage. This shows that the President is highly optimistic and tries to exude confidence in his ability to successfully lead his people to combat the virus. However, this call is not done in an ideological vacuum. Interestingly, just as the literature on ideology confirms that positive self-presentation and negative other presentation is expected, the attempt to create a united front caused the president not to descend heavily on the out-group represented by his political opponents. The following examples are given for illustration:

\section{Extract 21}

However, I'm deeply disturbed by the actions of $a$ few unpatriotic persons, who are deliberately passing off and circulating old videos of alleged brutality of security agencies, largely of foreign origin. ..05-04-2020

\section{Extract 22}

The cynics question our capacity for the maintenance of discipline in this period and its aftermath; however, I am confident that we will prove them wrong. Ghanaians always rise to the occasion and we will do so again. United, we are going to win this battle.05-04-2020

\section{Extract 23}

I know some political actors will want you to believe that our current numbers represent a failure on the part of Government. Do not begrudge them. They need to make such comments for their political survival. On the contrary, we must be emboldened that the 4700 persons infected have been identified, taken out of the population, isolated, and are being treated. 10-05-20

Throughout the speeches in extracts 21-23 above, he did not make direct attacks on his opponents. He talked about unpatriotic persons, the cynics, and some political actors; very indirect references to opponents. A close examination of all the utterances shows that he uses words that minimise the effect of the actions of the opponents and maximise the need for national cohesion. The president wants to be a unifying force rather than one encouraging division.

The same is not done for another outgroup represented by foreign nationals in the fight against fake news and misinformation, which are real enemies in the fight against COVID. The president almost presented the virus as an "imported" material and also made use of words that portray the Ghanaian as an improbable originator of fake news and misinformation.

\section{Extract 24}

The information we put out however must be that approved by Health authorities and not from any piece of literature found on the internet as false materials are being spread from other jurisdictions. (11-03-20)

\section{Extract 25}

Indeed, $97 \%$ of all confirmed cases are travellers who brought the disease from outside our shores. (28-03-2020)

\section{Extract 26}

Unhappily, there continues to be the worrying news .... Ghanaians aiding some West African nationals to enter our country illegally, despite the closure of our borders.... several of the West Africans, who have been arrested, 
have later tested positive for the virus. We have been spared the epidemics that have brought havoc to other nations in our neighbourhood (6-03-2020)

This is shown by the low values of the use of the pronoun "they "in extract 23. However, he had some veiled criticisms for those who spread fake news and those who aided others to "import "the virus to the shores of Ghana.

\subsection{LIWC2015 Output Variable Information of Linguistic Markers of Post Traumatic Growth}

The experience of a traumatic event can be disclosed through narratives, which can be linguistically analysed with the Linguistic Inquiry and Word Count (LIWC). Table 2. below presents the linguistic features that mark Post-Traumatic growth and their percentages in the Covid-19 addresses through the 2015 LIWC software.

Table 2. Linguistic Markers of Post-Traumatic Growth

\begin{tabular}{ll}
\hline Personal Pronouns & Percentages \% \\
\hline We & 3.17 \\
I & 1.07 \\
They & 0.75 \\
Positive Emotion & 2.89 \\
Negative Emotion & 1.24 \\
Analytic & 90.82 \\
Clout & 81.17 \\
Authentic & 21.41 \\
Tone & 57.14 \\
Perceptual Processes & 0.71 \\
Cognitive Processes & 7.17 \\
& \\
Time Orientation & \\
Focused past & 2.02 \\
Focused present & 7.01 \\
Focused future & 1.37 \\
& \\
Personal Concerns & \\
religion & 0.74 \\
death & 0.2 \\
money & 0.78 \\
work & 4.77 \\
\hline
\end{tabular}

The table above is analysed under three main variables of post-traumatic growth, personal pronouns, time orientation, and personal concerns.

The president used "we" as a personal pronoun predominantly in his speeches. This choice is not only a conscious effort to show national cohesion and unity against a fight with a common enemy but it is also an attempt at weaving a narrative that shows the long history of the enduring resilience and creativity of the Ghanaian. The use of "I" as a personal pronoun in most of the cases was used to carve an identity of a caring father, a great commander in chief, and a thoughtful and strong leader who is best fit to lead a resilient group of people to fight a virus. Extracts 27 and 28 illustrate President Nana Addo as a concerned leader.

\section{Extract 27}

I must repeat how proud I am to be your president in these difficult times 16-08-20

\section{Extract 28}

It is my job to protect you and I am determined to do just that; together by the grace of God.... 28-03-20

From Table 2, we see very clearly that percentages for analytic reasoning and clout are very high. It shows that the updates are very much a carefully thought-out speech that involved careful consideration of policies and measures marked by a need to provide reasons for all the actions and inactions of the president. 
Similarly, an investigation of the personal concerns of the president shows that the work he and Ghanaians have to do is his topmost priority followed by money. The rhetoric about money is linked to job creation and reviving the economy. Overall, the tone of the updates is positive since it is numbered below $50 \%$ that shows a negative tone. We can see that the president used the updates to show a positive orientation to the pandemic even when things sometimes get very alarming. Interestingly, time focus reveals that the president's address focused on the present but he relies on the past and future to get his message across.

The scores about the authenticity of the speeches which deal with how people candidly reveal themselves by being personal, humble, or vulnerable are low. This is not very surprising; these addresses are usually written by Presidential staffers for the president. Therefore, the writers would always want to show the power and dynamism of the President rather than his vulnerabilities. In a state of War, the last person to show vulnerability is the commander in chief.

\section{Conclusion}

A thorough reading of the updates to the nation showed a compelling case for Post-Traumatic growth and a conscious attempt to reconstruct a personal and national identity of growth and resilience. Threats beyond the pandemic are factored into the updates since as a nation, Ghanaians are divided by politics, ethnicity, football, and even the foods we eat.

Yet, to ensure national cohesion and unity, we rally around the national symbols and state institutions. Religions and the pervasiveness of a strong belief in the supernatural define a Ghanaian. People tell stories to define and construct who they are. These narratives are used to impose order and continuity on the concept of the self amid conflicting life changes. To maintain congruence between the identities constructed over several generations and emergent identities in the face of responding to traumatic experiences, the identity construction narratives have to accommodate change and consistency. Invariably, in the updates to the nation, Akuffo Addo uses narratives to forge congruence between the known Ghanaian identity and the threats that the pandemic poses, which he redefined to accommodate change while constructing a new identity that is based on the proverbial optimistic resilience and entrepreneurial spirit of the Ghanaian.

From the analysis of the updates, President Nana Akuffo Addo portrays Ghanaians as resilient, evolving, and optimistic people who rise above any threat. In doing this, he consciously hypes his own identity as a caring, forthright leader who empathises with the ordinary Ghanaian and is keenly aware of the sacrifices everyone must make to defeat the virus. On the other hand, he is aware of the existence of political opponents and other threats to his identity thus he craftily appeals to the common elements that define the Ghanaian as he presents copious reasons for all his actions or inactions in a bid to rally the whole nation together in fighting the pandemic which he construes as a common enemy.

In a country that is highly polarised politically with very close election results announced every four-year cycle, it could amount to political suicide if the citizens are not brought on board to fight the pandemic. The leader, therefore, had to align with the hopes and aspirations of the people while constructing an identity of a commander in chief who could be trusted by Ghanaians. The updates are thus seen as a political tool aimed at creating national cohesion amidst a traumatic experience.

The analysis showed that there was a high prevalence of personal pronoun use, use of positive emotion words, and cognitive processing words. This confirms our hypothesis that linguistic markers can be used to detect PTG.

\section{Suggestions for Further Study}

This paper has focused on strategies adopted by President Nana Addo to deal with the coronavirus pandemic and to foster post-traumatic growth among Ghanaians in the monthly addresses he delivers to them.

The present research could be extended by future researchers to include an analysis of Ghanaians post-traumatic behavioural response. A study could also be conducted on mass media impact in emergent public crisis, more specifically, the vocabulary used in mass media that encourages or discourages post-traumatic growth.

\section{References}

Bruce, R., Cavgias, A., Meloni, L., \& Remígio, M. (2021). Under pressure: Women's leadership during the COVID-19 crisis. Journal of Development Economics, 102761. https://doi.org/10.2139/ssrn.3883010

Cadagnone, C., Bogliacino, F., Gomez, C., Charris, R., Montealegre, F., Liva, G., et al. (2020). Assessing concerns for 
the economic consequence of the COVID-19 response and mental health problems associated with economic vulnerability and negative economic shock in Italy, Spain, and the United Kingdom. PLoS ONE, 15(10). https://doi.org/10.1371/journal.pone.0240876

Clifford, J. (1988). The Predicament of Culture. Twentieth-Century Ethnography, Literature, and Art. Cambridge, MA: Harvard University Press. https://doi.org/10.2307/j.ctvjf9x0h

Cohn, M. A., Mehl, M. R., \& Pennebaker, J. W. (2004). Linguistic markers of psychological change surrounding September 11, 2001. Psychological science, 15(10), 687-693. https://doi.org/10.1111/j.0956-7976.2004.00741.x

Dudău, D. P., \& Sava, F. A. (2021). Performing multilingual analysis with Linguistic Inquiry and Word Count 2015 (LIWC2015). An equivalence study of four languages. Frontiers in Psychology, 12, 2860. https://doi.org/10.3389/fpsyg.2021.570568

Ellena, A. M., Aresi, G., Marta, E., \& Pozzi, M. (2021). Posttraumatic growth dimensions differently mediate the relationship between national identity and interpersonal trust among young adults. A study on COVID-19 crisis in Italy. Frontiers in Psychology, 11, 3944. https://doi.org/10.3389/fpsyg.2020.576610

Hoyt, T., \& Pasupathi, M. (2008). Blogging about trauma: Linguistic markers of apparent recovery. E-Journal of Applied Psychology, 4, 56-62. https://doi.org/10.7790/ejap.v4i2.106

Kacewicz, E., Pennebaker, J. W., Davis, M., Jeon, M., \& Graesser, A. C. (2014). Pronoun use reflects standings in social hierarchies. Journal of Language and Social Psychology, 33(2), 125-143. https://doi.org/10.1177/0261927X13502654

Kleim, B., Horn, A. B., Kraehenmann, R., Mehl, M. R., \& Ehlers, A. (2018). Early linguistic markers of trauma-specific processing predict post-trauma adjustment. Frontiers in psychiatry, 9, 645. https://doi.org/10.3389/fpsyt.2018.00645

Lau, B. H. P., Chan, C. L. W., and Ng, S. M. (2020a). Resilience of hong kong people in the covid-19 pandemic: lessons learned from a survey at the peak of the pandemic in spring 2020. Asia pac. j. soc. work dev., 31, 105-114. https://doi.org/10.1080/02185385.2020.1778516

Lowe, S. R., Manove, E. E., \& Rhodes, J. E. (2013). Post-traumatic stress and posttraumatic growth among low-income mothers who survived hurricane katrina. Journal of consulting and clinical psychology, 81(5), 877-889. https://doi.org/10.1037/a0033252

Marshall, K., Abate, A., \& Venata, A. (2020). Posttraumatic stress symptoms and recidivism in serious juvenile offenders: testing the mediating role of future orientation. Journal of child \& adolescent trauma, 13(1), 33-43. https://doi.org/10.1007/s40653-018-0234-8

Matthew L. Spialek, J. Brian Houston \& Kyle C. Worley (2019) Disaster communication, posttraumatic stress, and posttraumatic growth following hurricane matthew. Journal of health communication, 24(1), 65-74. https://doi.org/10.1080/10810730.2019.1574319

Morris, B. A., Shakespeare-Finch, J., Rieck, M., \& Newberry, J. (2005) Multi-dimensional nature of Post Traumatic Growth in an Australian Population. Journal of Traumatic Stress, 18(5), 575-585. https://doi.org/10.1002/jts.20067

Nakagawa, S., Sugiura, M., Sekiguchi, A., Kotozaki, Y., Miyauchi, C. M., Hanawa, S., et al. (2016). Effects of post-traumatic growth on the dorsolateral prefrontal cortex after a disaster. Sci. Rep., 6, 343-64. https://doi.org/10.1038/srep34364

Nishi, D., Matsuoka, Y., \& Kim, Y. (2010). Posttraumatic growth, posttraumatic stress disorder and resilience of motor vehicle accident survivors. BioPsychoSocial Med., 4(7). https://doi.org/10.1186/1751-0759-4-7

Penebaker, J., Francis, M., \& Booth, R. (2001). Linguistic Inquiry and Word count (LIWC). Mahwah NJ Erlbaum.

Pennebaker, J. W., Boyd, R. L., Jordan, K., \& Blackburn, K. (2015). The development and psychometric properties of LIWC2015.

Salari, N., Hosseinian-Far, A., Jalali, R., Vaisi-Raygani, A., Rasoulpoor, S., Mohammadi, M. ... \& Khaledi-Paveh, B. (2020). Prevalence of stress, anxiety, depression among the general population during the COVID-19 pandemic: a systematic review and meta-analysis. Globalization and health, 16(1), 1-11. https://doi.org/10.1186/s12992-020-00589-w

Stallard, P., Pereira, A. I., \& Barros, L. (2021). Post-traumatic growth during the COVID-19 pandemic in carers of 
children in Portugal and the UK: cross-sectional online survey. BJPsych Open, 7(1). https://doi.org/10.1192/bjo.2021.1

Taku, K., Cann, A., Calhoun, I. G., \& Tedeschi, R. G. (2008) The factor structure of Post Traumatic Growth Inventory. A comparison of five models using confirmatory Factor Analysis. Journal of Traumatic Stress, 27(2), 156-164. https://doi.org/10.1002/jts.20305

Taylor, A., \& Berger, M. (2020). When it comes to coronavirus response, superpowers may need to study smaller nations. Retrieved from https://www.washingtonpost.com/world/2020/06/10/

Tedeschi, R. G., Park, C. L., \& Calhoun, L. G. (Eds.). (1998). Posttraumatic growth: Positive changes in the aftermath of crisis. Routledge. https://doi.org/10.1016/j.agrformet.2011.09.002

Teixeira, Edmar I., et al. (2013). Global hot-spots of heat stress on agricultural crops due to climate change. Agricultural and Forest Meteorology, 170, 206-215.

UNDP. (2021). Long-Term Socio-Economic Impacts of COVID-19 Across Diverse African Contexts. Retrieved 25/08 2021 from: https://www.africa.undp.org/content

Vázquez-Añón, M., Nocek, J., Bowman, G., Hampton, T., Atwell, C., Vazquez, P., \& Jenkins, T. (2008). Effects of feeding a dietary antioxidant in diets with oxidized fat on lactation performance and antioxidant status of the cow. Journal of dairy science, 91(8), 3165-3172. https://doi.org/10.3168/jds.2007-0737

Zenger, J., \& Folkman, J. (2020). Research: Women are better leaders during a crisis. Harvard Business Review.

Zoeller, T., \& Maercker, A. (2006). Post Traumatic Growth in Clinical Psychology. A critical review and introduction of a two-component model. Clinical Psychology Review, 26(5), 626-653. https://doi.org/10.1016/j.cpr.2006.01.008

\section{Copyrights}

Copyright for this article is retained by the author(s), with first publication rights granted to the journal.

This is an open-access article distributed under the terms and conditions of the Creative Commons Attribution license (http://creativecommons.org/licenses/by/4.0/). 